\title{
Identification of bacterial pathogens and determination of their antibacterial resistance profiles in some cultured fish in Turkey
}

\author{
Mustafa Türe, Hüseyin Alp \\ Central Fisheries Research Institute, 61250, Trabzon-Turkey \\ mustafa.ture@gthb.gov.tr
}

Received: November 30, 2015 Accepted: May 18, 2016

\begin{abstract}
Introduction: In the present study, some of the commercial fish farms located in the Black Sea region of Turkey, were screened for bacteria between 2012 and 2014. Material and Methods: The bacterial agents isolated from fish were identified by classical biochemical tests and the rapid diagnostic tests (API $20 \mathrm{E}$ and API 20 Strep). All strains were further identified by sequencing of the 16S rRNA genes. The strains were also investigated for resistance to different antimicrobials by the disc diffusion method. Antibiotic resistance genes, including tetracycline (B), $\beta$-lactam (ampC, blaTEM, blaPSE), florfenicol (floR), erythromycine (ereA, ereB), sulphonamide (sulI, sulII), and trimethoprim ( $d h f r l)$ genes, were determined by the PCR method. Results: Vibrio anguillarum, Vibrio fluvialis, Photobacterium damselae subsp. piscicida, Pseudomonas luteola, Lactococcus garvieae, Streptococcus iniae, Aeromonas hydrophila, and Yersinia ruckeri were isolated from marine and freshwater cultured fish. According to the results of disc diffusion, all isolates were sensitive to florfenicol, trimethoprim+sulfamethoxazole, oxitetracycline, and enrofloxacin, and resistant to lincomycin, penicillin G, and amoxicillin. Also, sulI, sulII, and floR resistance genes were detected in the bacteria. Conclusion: The results of the study open up the opportunity to perform further investigations which could determine the possible role of ARGs in fish pathogens.
\end{abstract}

Keywords: fish, bacteria, antibiotic resistance, resistance gene, Turkey.

\section{Introduction}

Aquaculture is a comparatively new industry for Turkey, which started with rainbow trout (Oncorhynchus mykiss) culture after the 1970s. Rainbow trout, sea bass (Dicentrarchus labrax), and sea bream (Sparus aurata) are the most extensively cultured fish species. According to the recent data, Turkey is one of the biggest fish producers among the European countries, and produces approximately 212000 tons of fish per year (24). The development of fish production engenders fish diseases and, as a result, economic losses. Success in aquaculture depends on effective fish health management. In spite of new drugs and developing culture techniques, bacterial diseases are still one of the most serious problems in aquaculture in the world (12).

Inappropriately used or misused antibiotics in aquaculture result in the occurrence of drug-resistant bacteria and antibiotic resistance genes (ARGs) in pathogenic bacteria of fish. Thus, antibiotic treatments sometimes fail on fish farms (1). Several kinds of antimicrobial agents have failed in the treatment of fish bacterial diseases in Turkey, including sulfamethoxazole, ampicillin, and aztreonam (6).

In the last decade there has started to be awareness regarding the potential transfer of antimicrobial resistant bacteria between animals and humans. The widespread distribution of resistance genes between bacteria of humans and those of animals is an outcome of horizontal gene transfer. Transference of resistance determinants occurs by mobile genetic elements such as conjugative plasmids, integron, phages, and transposons (13).

The studies on ARGs in bacteria isolated from fish are very limited, especially related to fish farms in Turkey. In this study, some of the commercial fish farms located in the Black Sea region of Turkey were screened for bacteria. The bacterial agents isolated from fish were identified by classical biochemical tests and rapid 
diagnostic tests. All strains of bacteria were further identified by sequencing of the $16 \mathrm{~S}$ rRNA genes. Antibiotic resistance and ARGs, including tetracycline (tetB), $\beta$-lactam (ampC, blaTEM, blaPSE), florfenicol (floR), erythromycin (ereA, ereB), sulphonamide (sulI, sulII), and trimethoprim (dhfrl) genes, were also determined in the bacterial isolates.

\section{Material and Methods}

Sampling and microbiological examination. A total of 240 fish from local rainbow trout farms were sampled between 2012 and 2014. Fish from six farms (three freshwater and three seawater) were examined for bacterial pathogens. Fish were randomly sampled considering absence of any noticeable disease in the ponds. For this purpose, fish samples from each farm were aseptically collected and transported to the laboratory in two seasons per year. The following species were examined: rainbow trout (Oncorhynchus mykiss), brook trout (Salvelinus fontinalis), and Black Sea trout (Salmo trutta labrax) from fresh water; turbot (Psetta maxima), sea bass (Dicentrarchus labrax), and sturgeon (Acipenser gueldenstaedtii) from sea water (Table 1). All collected fish were examined externally and internally. The body surfaces of the fish were swabbed with $70 \%$ ethyl alcohol before accessing internal organs. Then, liver, kidney, and spleen tissues were aseptically streaked onto thiosulfate citrate bile sucrose agar and tryptic soy agar (TCBS and TSA, Merck, Germany) and incubated at $20^{\circ} \mathrm{C}$ for $3 \mathrm{~d}$. All isolates were subcultured again on the same media to check the purity of the isolate. Pure cultured colonies were biochemically characterised with API 20 E or API 20 Strep (Biomerieux, France), Gram staining, and the following biochemical tests: cytochrome oxidase, catalase, and oxidation/fermentation. All isolates were identified to species level by standard bacterial taxonomy procedures (3).

Genomic DNA preparation and sequencing of bacteria. Genomic DNA of all isolates was extracted as a template for the PCR assay by a QIAamp DNA mini kit (Qiagen, Germany), according to the manufacturer's instructions. An RNA/DNA calculator (Spectrophotometer, Biorad, USA) was used to measure optical density at 260 and $280 \mathrm{~nm}$ (average A260/280 was 1.7). All strains were also identified by DNA sequencing of their 16S rRNA genes. A forward primer 63f (5'-CAG GCC TAA CAC ATG CAA GTC$\left.3^{\prime}\right)$ and reverse primer $1387 \mathrm{r}$ (5'-GGG CGG WGT GTA CAA GGC-3') were used for PCR amplification of a less conserved region of the small subunit 16S rRNA gene sequence of bacterial isolates (15) and synthesised by Integrated DNA Technologies (USA). PCR was performed with PCR master mix (Qiagen) in a thermal cycler (SensQuest, Germany). PCR products were purified with a NucleoSpin PCR purification kit (Invitrogen, USA) and directly sequenced on an Applied 3500 genetic analyser (Applied Biosystems, USA). The derived nucleotide sequences were analysed and aligned with the BioEdit Sequence Alignment Editor (8).

Antibiotic susceptibility testing. Antibiotic susceptibility was determined by the disc diffusion method using $6 \mathrm{~mm}$ diameter commercial discs (Oxoid, U.K.) on Mueller Hinton agar (MHA) (Oxoid, U.K.) plates according to the Clinical and Laboratory Standards Institute guidelines (7). Commercial antibiotic discs included ( $\mu \mathrm{g} /$ disc): tetracycline (TE, 30); amoxicillin (AML, 10); enrofloxacin (ENR, 5); florfenicol (FFC, 30); lincomycin (LM, 10); oxytetracycline (OXT, 30); ampicillin (AM, 10); erythromycin (ER, 15); penicillin $\mathrm{G}$ (P, 10U); and trimethoprim + sulfamethoxazole (TSX, 25). The bacteria were incubated overnight at $30^{\circ} \mathrm{C}$ and bacterial optical density was adjusted to be approximately equal to 0.5 McFarland opacity. The bacterial suspension $(0.1 \mathrm{~mL})$ was poured and spread on MHA plates. Antibiotic discs were dispensed onto the surface of the plates, and the plates were incubated aerobically for $22 \mathrm{~h}$ at 30 and $37^{\circ} \mathrm{C}$ for Gram positive and negative bacteria respectively. After incubation, the zone diameters were measured (25).

Multiple antibiotic resistance (MAR) index. For all isolates, MAR index values $(\mathrm{A} / \mathrm{B})$ were calculated for each (A represents the number of antibiotics the isolate was resistant to, and B represents the total number of antibiotics the isolate was tested against). In general, a MAR index value $>0.2$ was observed when the isolate was exposed to high-risk sources of contamination where antibiotic use is common (11).

PCR assays for detection of ARGs. All isolates were tested for the presence of ARGs. The presence of ARGs, including tetracycline, oxytetracycline (tetB), $\beta$-lactam (ampC, blaTEM, blaPSE), florfenicol (floR), erythromycin (ereA, ereB), sulphonamide (sulI, sulII), and trimethoprim $(d h f r A l)$, was analysed by PCR. Target genes and primers used for PCR are shown in Table 2. Each PCR reaction mix $(25 \mu \mathrm{L})$ contained $100 \mathrm{ng}$ of sample DNA, $100 \mathrm{ng}$ of each primer, $12.5 \mu \mathrm{L}$ of 2X PCR Master Mix solution (Master PCR kit, Qiagen, Germany), and $9.5 \mu \mathrm{L}$ of distilled water. $\mathrm{MgCl}_{2}$ concentration was optimised for each primer set. As a negative control, all primer sets were tested with sterilised water. DNA amplification was performed in a thermocycler (SensQuest, Germany) under the following conditions: initial denaturation at $94^{\circ} \mathrm{C}$ for $5 \mathrm{~min}$, followed by 35 cycles of denaturation at $94^{\circ} \mathrm{C}$ for $30 \mathrm{~s}$, annealing for $30 \mathrm{~s}$, extension at $72^{\circ} \mathrm{C}$ for $45 \mathrm{~s}$, and final extension at $72^{\circ} \mathrm{C}$ for $10 \mathrm{~min}$. Five microlitres of PCR products was subjected to electrophoresis in $1.5 \%(\mathrm{w} / \mathrm{v})$ agarose gel prepared with $1 \mathrm{x}$ TAE (TrisAcetate-EDTA) buffer and run at $100 \mathrm{~V}$ for $1 \mathrm{~h}$. Then, the PCR products were stained with ethidium bromide and viewed by UV transillumination. The sizes of the PCR products were determined by a 100 bp DNA ladder (Bio Basic, Canada). 
Table 1. Bacteria isolated from different fish species and/or sampling organs

\begin{tabular}{|c|c|c|c|c|c|}
\hline Fish pathogens & Species & $\begin{array}{l}\text { Sampling } \\
\text { point }\end{array}$ & $\mathrm{N}$ & $\begin{array}{l}\text { Average } \\
\text { fish size (g) }\end{array}$ & $\begin{array}{l}\text { Isolated } \\
\text { from }\end{array}$ \\
\hline Aeromonas hydrophila & Brook trout & Fresh water & 30 & 20 & $\mathrm{~K}, \mathrm{~L}$ \\
\hline Photobacterium demselae subsp. piscicida & Sturgeon & Sea water & 5 & 60 & $\mathrm{~L}$ \\
\hline Vibrio fluvialis & Sea bass & Sea water & 20 & 100 & $\mathrm{~K}, \mathrm{~L}$ \\
\hline Vibrio anguillarum $\left(\mathrm{V}_{1}\right)$ & Rainbow trout & Sea water & 30 & 50 & $\mathrm{~K}, \mathrm{~L}, \mathrm{~S}$ \\
\hline Vibrio anguillarum $\left(\mathrm{V}_{2}\right)$ & Rainbow trout & Sea water & 30 & 50 & $\mathrm{~K}, \mathrm{~L}$ \\
\hline Pseudomonas luteola & Turbot & Sea water & 15 & 40 & $\mathrm{~K}, \mathrm{~L}$ \\
\hline Yersinia ruckeri & Rainbow trout & Fresh water & 30 & 30 & $\mathrm{~K}, \mathrm{~L}, \mathrm{~S}$ \\
\hline Streptococcus inia & Brook trout & Fresh water & 30 & 20 & $\mathrm{~K}$ \\
\hline Lactococcus garvieae (L1) & Rainbow trout & Fresh water & 30 & 40 & $\mathrm{~K}, \mathrm{~L}, \mathrm{~S}$ \\
\hline Lactococcus garvieae (L2) & Rainbow trout & Fresh water & 20 & 60 & $\mathrm{~K}, \mathrm{~L}, \mathrm{~S}$ \\
\hline
\end{tabular}

$\mathrm{N}$ - number of sampled fish, $\mathrm{K}$ - kidney, $\mathrm{L}$ - liver, $\mathrm{S}$ - spleen

Table 2. Primers used in the PCR reactions

\begin{tabular}{|c|c|c|c|c|}
\hline Primer name & Sequence $\left(5^{\prime}-3^{\prime}\right)$ & Target gene & Product size & Reference \\
\hline $\begin{array}{l}\text { ereA-F } \\
\text { ereA-R }\end{array}$ & $\begin{array}{l}\text { AACACCCTGAACCCAAGGGACG } \\
\text { CTTCACATCCGGATTCGCTCGA }\end{array}$ & ereA & 420 & (18) \\
\hline $\begin{array}{l}\text { ereB-F } \\
\text { ereB-R }\end{array}$ & $\begin{array}{l}\text { AGAAATGGAGGTTCATACTTACCACAT } \\
\text { ATAATCATCACCAATGGCA }\end{array}$ & ereB & 546 & (2) \\
\hline $\begin{array}{l}\text { TetB-F } \\
\text { TetB-R }\end{array}$ & $\begin{array}{l}\text { TTGGTTAGGGGCAAGTTTTG } \\
\text { GTAATGGGCCAATAACACCG }\end{array}$ & tet $B$ & 659 & (16) \\
\hline $\begin{array}{l}\text { SulI-F } \\
\text { Sull-R }\end{array}$ & $\begin{array}{l}\text { CGGCGTGGGCTACCTGAACG } \\
\text { GCCGATCGCGTGAAGTTCCG }\end{array}$ & sulI & 433 & \\
\hline $\begin{array}{l}\text { SulII-F } \\
\text { SulII-R }\end{array}$ & $\begin{array}{l}\text { GCGCTCAAGGCAGATGGCATT } \\
\text { GCGTTTGATACCGGCACCCGT }\end{array}$ & sullI & 293 & (10) \\
\hline $\begin{array}{l}\text { TEMOT-F } \\
\text { TEMOT-R }\end{array}$ & $\begin{array}{l}\text { ATGAGTATTCAACATTTCCG } \\
\text { CAATGCTTAATCAGTGAGG }\end{array}$ & bla $_{\text {tem }}$ & 859 & (17) \\
\hline $\begin{array}{l}\text { PSE1-F } \\
\text { PSE1-R }\end{array}$ & $\begin{array}{l}\text { CGCTTCCCGTTAACAAGTAC } \\
\text { CTGGTTCATTTCAGATAGCG }\end{array}$ & bla $_{p s e}$ & 465 & (5) \\
\hline $\begin{array}{l}\text { AmpC-F } \\
\text { AmpC-R }\end{array}$ & $\begin{array}{l}\text { TTCTATCAAMACTGGCARCC } \\
\text { CCYTTTTATGTACCCAYGA }\end{array}$ & ampC & 550 & (21) \\
\hline $\begin{array}{l}\text { dhfr1-F } \\
\text { dhfr1 R }\end{array}$ & $\begin{array}{l}\text { CTGATATTCCATGGAGTGCCA } \\
\text { CGTTGCTGCCACTTGTTAACC }\end{array}$ & $d h f r l$ & 433 & (20) \\
\hline $\begin{array}{l}\text { floR-F } \\
\text { floR-R }\end{array}$ & $\begin{array}{l}\text { TATCTCCCTGTCGTTCCAG } \\
\text { AGAACTCGCCGATCAATG }\end{array}$ & floR & 399 & (26) \\
\hline
\end{tabular}

\section{Results}

Different bacterial species were isolated during the screening of fish for two years. The bacteria were identified to species level by sequencing of the 16S rRNA genes. 16S rRNA gene sequences of V. anguillarum, A. hydrophila, S. inia, L. garvieae, $Y$. ruckeri, $P$. luteola, $P$. damselae, and V. fluvialis strains were demonstrated to have $>97 \%$ similarity with reference strains (accession numbers: NC 006841, NC 009348, NC 017490, NC 017490, KN 150747, NC 007557, NC 006840, and NC 006841) from Genbank. A total of eight species were isolated. Vibrio anguillarum, Vibrio fluvialis, Photobacterium damselae subsp. piscicida, and Pseudomonas luteola were isolated from rainbow trout, sea bass, sturgeon, and turbot, one species from each fish. Streptococcus inia, Lactococcus garvieae, Aeromonas hydrophila, and Yersinia ruckeri were isolated from brook trout, rainbow trout, brook trout, and rainbow trout respectively. The results of the rapid diagnostic tests and classical biochemical tests are shown in Tables 3 and 4. Antimicrobial susceptibility tests indicated that $100 \%$ of the bacteria were resistant to lincomycin, followed by amoxicillin (80\%), penicillin (70\%), ampicilin (50\%), tetracycline and erythromycin (30\%), oxytetracycline and trimethoprim + sulfamethoxazole (20\%), and enrofloxacine (10\%). The most effective antibiotic was florfenicol (Table 5). The highest MAR index value in the bacteria was 0.6 in $V$. fluvialis, V. anguillarum $\left(\mathrm{V}_{1}, \mathrm{~V}_{2}\right)$, and Streptecoccus inia. These species were resistant to 6 out of 10 antibiotics. MAR values for nearly all bacteria were above the critical level of 0.20 , the average MAR index value being 0.41 (Fig. 1). In addition to phenotypic antimicrobial resistance of the bacteria, ARGs of the bacteria and results of PCR assays were shown in Fig. 2. ARGs resulted in the amplification of DNA fragments with various band intensities, and their sizes ranged between 293 (SulII) and 433 (SulI) bp (Fig. 2). V. fluvialis and Y. ruckeri isolates had SulII ARG, and $V$. anguillarum $\left(\mathrm{V}_{1}\right)$ isolate had SulI ARG. Furthermore, floR ARG was detected in V. Fluvialis and L. garvieae $\left(\mathrm{L}_{1}\right)$ strains. 


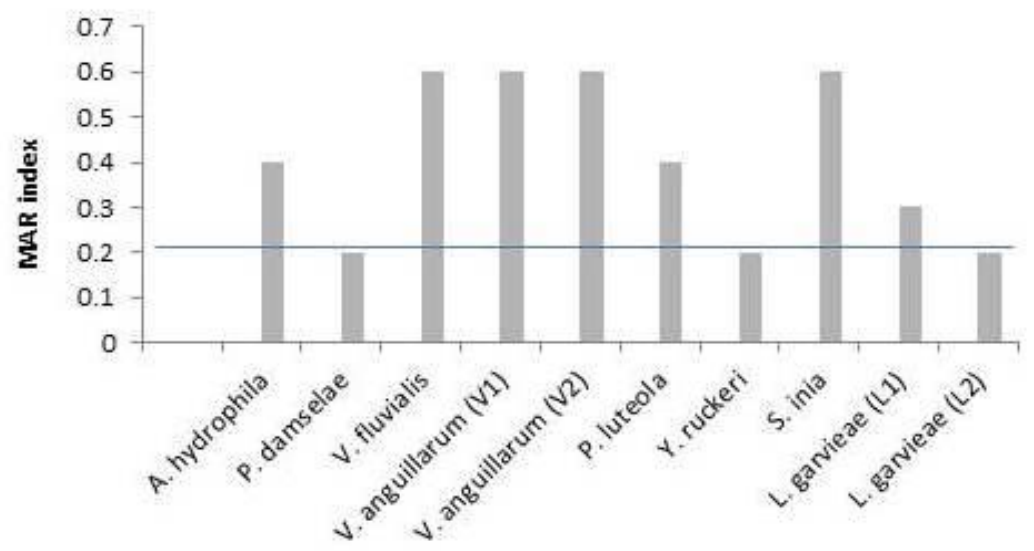

Bacterial species

Fig. 1. MAR index values of fish bacteria. Horizontal line indicates the MAR critical limit of 0.2

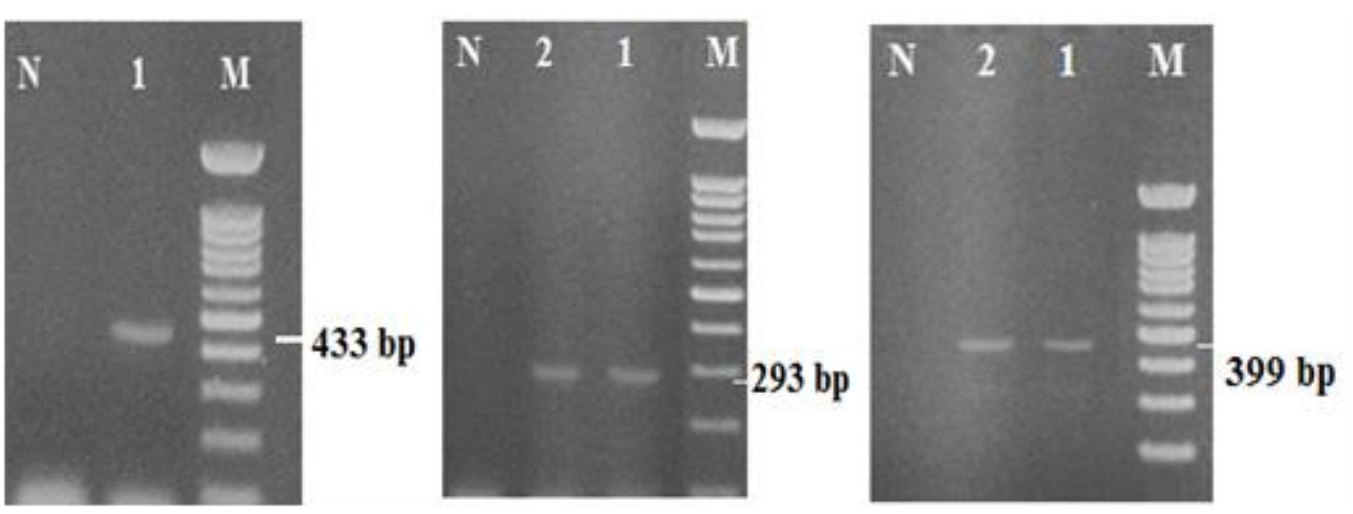

Fig. 2. Gel electrophoresis image of different resistance genes. M - 100-bp DNA marker, sulI (433 bp), sulII (293 bp), and floR (399), (from left to right), N - negative control containing PCR reagents alone

Table 3. Biochemical characteristics of bacteria isolated from fish

\begin{tabular}{|c|c|c|c|c|c|c|c|c|c|c|c|c|c|c|c|c|c|c|}
\hline Bacteria & Gram & OX & CAT & MOB & ONPG & $\mathrm{ADH}$ & CIT & $\mathrm{H}_{2} \mathrm{~S}$ & IND & GLU & MAN & INO & SOR & RHA & SAC & MEL & AMY & ARA \\
\hline A. hydrophila & - & + & + & + & + & + & + & - & - & + & + & - & - & - & - & - & + & - \\
\hline $\begin{array}{l}\text { P. damselae subsp. } \\
\text { piscicida }\end{array}$ & - & + & + & $\mathrm{Z}$ & - & - & - & - & - & + & - & + & - & - & - & + & + & - \\
\hline$V$. fluvialis & - & + & + & + & - & + & + & - & - & + & + & - & - & + & + & - & - & - \\
\hline V. anguillarum $\left(\mathrm{V}_{1}\right)$ & - & + & + & + & + & + & + & - & + & + & + & - & + & - & + & - & - & - \\
\hline V. anguillarum $\left(\mathrm{V}_{2}\right)$ & - & + & + & + & + & + & - & - & + & + & + & - & + & - & + & - & - & - \\
\hline P. luteola & - & + & + & + & + & + & + & - & - & + & - & - & - & - & - & - & - & + \\
\hline Y. ruckeri & - & - & + & + & + & + & + & - & - & + & + & - & - & - & - & - & - & - \\
\hline
\end{tabular}

$\mathrm{Z}$ - poor; API $20 \mathrm{E}$ and API 20 Strep tests were performed for Gram $(-)$ and Gram(+) bacteria respectively. Inconclusive results were obtained in the API 20 Strep test for Gram (+) bacteria

Table 4. Biochemical characteristics of bacteria isolated from fish

\begin{tabular}{|c|c|c|c|c|c|c|c|c|c|c|c|c|c|c|c|c|c|c|c|c|}
\hline Bacteria & Gram & $\mathrm{OX}$ & VP & HIP & ESC & PYR & $\alpha \mathrm{GAL}$ & $\beta G U R$ & $\beta G A L$ & PAL & LAP & $\mathrm{ADH}$ & RIB & ARA & MAN & SOR & LAC & TRE & RAF & AMD \\
\hline S. inia & + & - & - & - & + & - & - & + & - & + & + & + & + & - & - & - & + & + & - & + \\
\hline L. garvieae (L1) & + & - & + & + & + & + & - & - & - & - & + & + & + & - & + & - & + & + & - & + \\
\hline L. garvieae (L2) & + & - & + & - & + & - & - & - & - & - & + & + & + & - & + & - & + & + & - & + \\
\hline
\end{tabular}

$\mathrm{Z}$ - see Table 3 
Table 5. Antibiotic resistance profiles of bacterial isolates

\begin{tabular}{|c|c|c|c|c|c|c|c|c|c|c|}
\hline \multirow{2}{*}{ Strains } & \multicolumn{10}{|c|}{ Antibiotics } \\
\hline & $\mathrm{TE}$ & AML & ENR & FFC & $\mathrm{L}$ & OT & $\mathrm{AM}$ & $\mathrm{E}$ & $\mathrm{P}$ & TS \\
\hline A. hydrophila & $\mathrm{S}(21)$ & $\mathrm{R}(0)$ & $\mathrm{S}(31)$ & $\mathrm{S}(34)$ & $\mathrm{R}(0)$ & $\mathrm{S}(25)$ & $\mathrm{R}(0)$ & $\mathrm{I}(14)$ & $\mathrm{R}(0)$ & $S(27)$ \\
\hline P. damselae spp & $\mathrm{S}(20)$ & $\mathrm{I}(16)$ & $\mathrm{S}(25)$ & $\mathrm{S}(22)$ & $\mathrm{R}(0)$ & $\mathrm{S}(21)$ & $\mathrm{S}(19)$ & $\mathrm{I}(16)$ & $\mathrm{R}(9)$ & $S(22)$ \\
\hline V. fluvialis & $\mathrm{R}(10)$ & $\mathrm{R}(0)$ & $\mathrm{S}(19)$ & $\mathrm{S}(20)$ & $\mathrm{R}(0)$ & $\mathrm{R}(12)$ & $\mathrm{R}(0)$ & $\mathrm{I}(14)$ & $\mathrm{R}(0)$ & $S(27)$ \\
\hline V. anguill. $\left(\mathrm{V}_{1}\right)$ & $\mathrm{S}(18)$ & $\mathrm{R}(0)$ & $\mathrm{S}(23)$ & $\mathrm{I}(16)$ & $\mathrm{R}(0)$ & $\mathrm{S}(20)$ & $\mathrm{R}(0)$ & $\mathrm{R}(0)$ & $\mathrm{R}(0)$ & $\mathrm{R}(0)$ \\
\hline V. anguill. $\left(\mathrm{V}_{2}\right)$ & $\mathrm{S}(20)$ & $\mathrm{R}(0)$ & $\mathrm{I}(18)$ & $\mathrm{I}(15)$ & $\mathrm{R}(0)$ & $\mathrm{S}(20)$ & $\mathrm{R}(13)$ & $\mathrm{R}(0)$ & $\mathrm{R}(0)$ & $\mathrm{R}(0)$ \\
\hline Pseudomonas & $\mathrm{R}(11)$ & $\mathrm{R}(11)$ & $S(36)$ & $\mathrm{S}(30)$ & $\mathrm{R}(0)$ & $S(20)$ & $\mathrm{I}(16)$ & $\mathrm{R}(0)$ & $S(16)$ & $\mathrm{S}(34)$ \\
\hline Y. ruckeri & $\mathrm{S}(19)$ & $S(19)$ & $\mathrm{S}(30)$ & $\mathrm{S}(21)$ & $\mathrm{R}(0)$ & $\mathrm{S}(21)$ & $S(19)$ & $\mathrm{I}(20)$ & $\mathrm{R}(11)$ & $S(22)$ \\
\hline Streptococcus & $\mathrm{R}(14)$ & $\mathrm{R}(0)$ & $\mathrm{S}(30)$ & $\mathrm{S}(29)$ & $\mathrm{R}(0)$ & $\mathrm{R}(12)$ & $\mathrm{R}(0)$ & $\mathrm{I}(17)$ & $\mathrm{R}(0)$ & $\mathrm{S}(22)$ \\
\hline L. garvieae $\left(\mathrm{L}_{1}\right)$ & $\mathrm{S}(22)$ & $\mathrm{R}(0)$ & $\mathrm{R}(17)$ & $S(26)$ & $\mathrm{R}(12)$ & $\mathrm{S}(19)$ & $S(26)$ & $\mathrm{I}(20)$ & $S(23)$ & $S(17)$ \\
\hline L. garvieae $\left(\mathrm{L}_{2}\right)$ & $\mathrm{S}(28)$ & $\mathrm{R}(0)$ & $\mathrm{S}(25)$ & $\mathrm{S}(34)$ & $\mathrm{R}(0)$ & $\mathrm{S}(29)$ & $\mathrm{S}(35)$ & $\mathrm{S}(33)$ & $S(26)$ & $S(23)$ \\
\hline
\end{tabular}

TE - tetracycline, AML - amoxicilline, ENR - enrofloxacin, FFC - florfenicol, L - lincomycin, OT - oxytetracycline, AM - ampicillin, E - erythromycin, P - penicillin G, TS - trimethoprim+sulphamethoxazol, R - resistant, S - susceptible, I - intermediate, zone diameter - mm

\section{Discussion}

The pathogenic fish bacteria characteristic for aquaculture are usually present in wild fish populations. However, they seldom cause mortality due to the lack of stressful conditions in natural environments (23). In recent years, lactococcosis, vibriosis, motile aeromonas septicaemia, furunculosis, yersiniosis, photobacteriosis, and flavobacteriosis have been among the most frequently reported fish diseases in Turkey (19). In the present study, L. garvieae and $V$. anguillarum are the most frequently isolated fish pathogens. Additionally, Photobacterium damselae subsp. piscicida was first isolated in cultured sturgeon in Turkey.

Antibiotics are generally used worldwide for treating diseases caused by pathogenic bacteria in humans and animals, including fish. Inappropriately used antibiotics may accelerate the acquirement of ARGs in pathogenic fish bacteria. Genetic mechanisms involved in horizontal transfer of ARGs among pathogenic bacteria include conjugative transfer by mobile elements including plasmids, transposons, gene cassettes, and integrons (27).

In this study, some fish species were screened for bacteria between 2012 and 2014. The bacterial agents isolated from fish were identified by classical biochemical tests, the rapid diagnostic tests, and sequencing of the $16 \mathrm{~S}$ rRNA. All strains were also tested for their antibiotic resistance profiles. All isolates were sensitive to florfenicol, enrofloxacin, oxitetracyclin, and trimethoprim+sulfamethoxazole, and resistant to lincomycin, amoxicillin, and penicillin $\mathrm{G}$.

Ampicillin, neomycin, kanamycin, imipenem, erythromycin, oxolinic acid, oxitetracycline, trimethoprim+sulfamethoxazole, and streptomycin are commonly used antibiotics in several European countries and Turkey for treating fish diseases $(6,9)$. Amphenicol antibiotic (florfenicol) was introduced to aquaculture only a few years ago (9). Therefore, most bacteria should not be resistant to it. In the present study, none of the isolates were resistant to this antibiotic. However, floR ARG was detected in $V$. fluvialis and L. garvieae strains. By contrast, sulfamethoxazole is the most commonly used antibiotic in fish farms in Turkey, and $100 \%$ of the fish bacteria were found to be resistant to sulfamethoxazole (6). In the present study, antimicrobial susceptibility test results indicated that $80 \%$ of the bacteria were sensitive to trimethoprim+sulfamethoxazole. SulI and SulII ARGs were also detected in some of the isolates.

Photobacteriosis, caused by Photobacterium damselae subsp. damselae, is skin ulceration. The bacterium was isolated from cultured sea bass, rainbow trout, and horse mackerel (Trachurus mediterraneus) in Turkey (19). It was first isolated in cultured sturgeon in Turkey but it was not considered a cause of mortality. This bacterium was resistant to lincomycin and penicillin $G$ and was not harboured by ARG. L. garvieae was observed first in 1993 in Turkey. In the last decade there has started to be awareness about the disease in Turkey. It was demonstrated that $\beta$-lactam antibiotics and florfenicol were the most effective compounds in growth inhibition of L. garvieae (25). In the present study, L. garvieae was isolated from fish from two trout farms. These bacteria were resistant to lincomycin and amoxicillin; however, floR ARG was detected in one of two isolates.

In contrast to the results detailed in this study, it was reported that ARGs were commonly detected in Gram-negative bacteria in Turkey $(4,5)$. The prevalence of ARGs in Gram-negative bacteria, including $A$. hydrophila, $P$. damselae damselae, $V$. vulnificus, and Y. ruckeri from aquatic environments in Turkey, has previously been studied. The most prevalent resistance genes were found to be $\beta$-lactam (blaTEM), tetracycline (tetA, tetB), and $\operatorname{SulII}(4,5)$.

MAR index values $>0.2$ are regarded as an indicator of antimicrobial contamination (12). We 
found MAR index values ranging between 0.20 and 0.60 for pathogenic fish bacteria. The average MAR index value was calculated at 0.41 . These results are in agreement with previously published studies $(6,22)$.

The investigation of ARGs in bacteria isolated from fish is important with regard to the potential transportation of ARGs from fish pathogens to human bacterial pathogens (14). In this study, we investigated the fish diseases caused by common bacteria. Antimicrobial resistance and resistance genes of the bacteria isolated from fish were also examined. In conclusion, the frequency of resistance to lincomycin, amoxicillin, and penicillin remained high in pathogenic fish bacteria. However, some of the strains possessed SulI, SulII, and floR ARGs. The results of this study provided insights into understanding the resistance mechanisms of some fish pathogens. Our results open up the opportunity to perform further studies that could determine the possible role of ARGs in fish pathogens.

Conflict of Interests Statement: The authors declare that there is no conflict of interests regarding the publication of this article.

Financial Disclosure Statement: This study was funded by the Central Fisheries Research Institute (CFRI).

Animal Rights Statement: Experiments on animals were conducted in accordance with National and Institutional Guidelines for the protection of animal welfare.

\section{References}

1. Aoki T.: Present and future problems concerning the development of resistance in aquaculture. In: Chemotherapy in aquaculture: from theory to reality. Edited by Michel C. and Alderman D. Office International des Epizooties, Paris, 1992, pp. 254-262.

2. Arthur M., Autissier D., Courvalin P.: Analysis of the nucleotide sequence of the $e r e B$ gene encoding the erythromycin esterase type II. Nucleic Acids Res 1986, 14, 4987-4999.

3. Austin B., Austin D.A.: Bacterial Fish Pathogens Disease in Farmed and Wild Fish, Praxis Publishing, Chichester, UK, 2007, p. 533.

4. Balta F., Sandalli C., Kayis S., Ozgumus O.B.: Molecular analysis of antimicrobial resistance in Yersinia ruckeri strains isolated from rainbow trout (Oncorhynchus mykiss) grown in commercial fish farms in Turkey. Bull Eur Assoc Fish Path 2010, 30, 211-219.

5. Boran H., Terzi E., Altinok I., Capkin E., Bascinar N.: Bacterial diseases of cultured Mediterranean horse mackerel (Trachurus mediterraneus) in sea cages. Aquaculture 2013, 8, 396-399.

6. Capkin E., Terzi E., Altinok I.: Occurrence of antibiotic resistance genes in culturable bacteria isolated from Turkish trout farms and their local aquatic environment. Dis Aquat Org 2015, 114, 127-137.

7. CLSI.: Performance standards for antimicrobial susceptibility testing; Twenty-first Informational Supplement, M100-S21, 2011, 31, 1 .
8. Hall T.A.: A user-friendly biological sequence alignment editor and analysis program for Windows 95/98/NT, Nucl Acids Symp Ser 1999, 41, 95-98.

9. Kayis S., Capkin E., Balta F., Altinok I.: Bacteria in rainbow trout (Oncorhynchus mykiss) in the southern Black Sea Region of Turkey - A survey. Isr J Aquacult-Bamid 2009, 61, 339-344.

10. Kerrn M.B., Klemmensen T.F., Moller N., Espersen F. Susceptibility of Danish Escherichia coli strains isolated from urinary tract infections and bacteraemia, and distribution of sul genes conferring sulphonamide resistance. J Antimicrob Chemother 2002, 50, 513-516.

11. Krumperman P.H.: Multiple antibiotic resistance indexin of Escherichia coli to identify high-risk sources of fecal contamination of foods. Appl Environ Microbiol 1983, 46, $165-170$.

12. Kusuda R., Kawai K.: Bacterial diseases of cultured marine fish in Japan. Fish Pathol 1998, 33, 221-227.

13. Levy S.B., Marshall B.: Antibacterial resistance worldwide: causes, challenges and responses. Nat Med 2004, 10, 122-129.

14. Li J., Yie J., Foo R.W.T., Ling J.M.L., Xu H., Woo N.Y.S.: Antibiotic resistance and plasmid profiles of Vibrio isolates from cultured silver sea bream, Sparus sarpa. Mar Pollut Bull 1999, 39, 245-249.

15. Marchesi J.: Design and evaluation of useful bacterium-specific PCR primers that amplify genes coding for bacterial $16 \mathrm{~S}$ rRNA. Appl Environ Microbiol 1998, 64, 795-799.

16. Ng L.K., Martin I., Alfa M., Mulvey M.: Multiplex PCR for the detection of tetracycline resistant genes. Mol Cell Probe 2001, $15,209-215$

17. Olesen I., Hasman H., Aarestrup F.M.: Prevalence of $\beta$-lactamases among ampicillin-resistant Escherichia coli and Salmonella isolated from food animals in Denmark. Microb Drug Resist 2004, 10, 334-340.

18. Ounissi H., Courvalin P.: Nucleotide sequence of the gene ereA encoding the erythromycin esterase in Escherichia coli. Gene 1985, 35, 271-278.

19. Oztürk R.C., Altinok I.: Bacterial and viral fish diseases in Turkey. Turk J Fish Aquat Sc 2014, 14, 275-297.

20. Schmidt A.S., Bruun M.S., Larsen J.L., Dalsgaard I.: Characterization of class 1 integrons associated with R-plasmids in clinical Aeromonas salmonicida isolates from various geographical areas. J Antimicrob Chemother 2001, 47, 735-743.

21. Schwartz T., Kohnen W., Jansen B., Obst U.: Detection of antibiotic-resistant bacteria and their resistance genes in waste water, surface water, and drinking water biofilms. FEMS Microbiol Ecol 2003, 43, 325-335.

22. Su H.C., Ying G.G., Tao R., Zhang R.Q., Fogarty L.R. Occurrence of antibiotic resistance and characterization of resistance genes and integrons in Enterobacteriaceae isolated from integrated fish Farms in South China, J Environ Monit 2011, 13, 3229-3236.

23. Toranzo A.E., Magarinos B., Romalde J.L.: A review of the main bacterial fish diseases in mariculture systems. Aquaculture 2005, 246, 37-61.

24. TUIK.: Turkish Statistical Institute, http://www.turkstat. gov.tr/Start.do, 2014, Access date: 04.06.2015.

25. Ture M., Boran H.: Phenotypic and genotypic antimicrobial resistance of Lactococcus sp. strains isolated from rainbow trout (Oncorhynchus mykiss). Bull Vet Inst Pulawy 2015, 59, 37-42.

26. Van T.T.H., Chin J., Chapman T., Tran L.T., Coloe P.J.: Safety of raw meat and shellfish in Vietnam: an analysis of Escherichia coli isolations for antibiotic resistance and virulence genes. Int $\mathrm{J}$ Food Microbiol 2008, 124, 217-223

27. Zhang X.X., Zhang T., Fang H.H.P.: Antibiotic resistance genes in water environment. Appl Microbiol Biotechnol 2009, 82, $397-414$. 